\title{
Function and Expression of ATP-Binding Cassette Transporters in Cultured Human Y79 Retinoblastoma Cells
}

\author{
Yuka Ishikawa, Junya Nagai, Yumi Okada, Koya Sato, Ryoko Yumoto, and Mikihisa Takano* \\ Department of Pharmaceutics and Therapeutics, Graduate School of Biomedical Sciences, Hiroshima University; 1-2-3 \\ Kasumi, Minami-ku, Hiroshima 734-8553, Japan. \\ Received September 25, 2009; accepted December 21, 2009; published online December 25, 2009
}

\begin{abstract}
The aim of this study was to reveal the expression and function of P-glycoprotein and multidrug resistanceassociated proteins (MRP), members of the ATP-binding cassette (ABC) superfamily of drug transporters, in cultured human Y79 retinoblastoma cells. ABC transporter mRNA expression was evaluated by conventional reverse transcription-polymerase chain reaction (RT-PCR) and real-time PCR analyses. Cellular accumulation of rhodamine 123 (P-glycoprotein substrate), calcein (MRP substrate), and doxorubicin (P-glycoprotein/MRP substrate) was analyzed by fluorometry. Conventional RT-PCR analysis showed the expression of multidrug resistance 1 (MDR1), MRP1, MRP2 and lung resistance-related protein (LRP) mRNAs. Real-time RT-PCR analysis revealed that the expression levels of the MDR1 and MRP2 genes in Y79 cells were much lower than those in human intestinal cell line Caco-2, while the expression level of MRP1 was higher than that in Caco-2 cells. The accumulation of rhodamine 123 was not enhanced by verapamil or reversin 205, inhibitors of P-glycoprotein, indicating no function of P-glycoprotein in Y79 cells. The accumulation of calcein was significantly increased by various MRP inhibitors including probenecid, indicating that MRP functions in Y79 cells. The accumulation of doxorubicin was increased in the presence of metabolic inhibitors $(10 \mathrm{~mm}$ 2-deoxyglucose and 5 mu sodium azide). However, most MRP inhibitors such as probenecid and indomethacin did not affect doxorubicin accumulation, while cyclosporin A and taclorimus significantly increased doxorubicin accumulation. These results suggest that MRP, but not P-glycoprotein, functions in Y79 cells, and that the efflux of doxorubicin from Y79 cells may be due to an ATP-dependent transporter, which has not been identified yet.
\end{abstract}

Key words ATP-binding cassette transporter; retinoblastoma; Y79 cell

Resistance of cancer cells to chemotherapy is a serious problem for cancer treatment. Such resistance may develop during drug treatment or may be an inherent feature of a particular tumor type. The $170 \mathrm{kDa}$ multidrug resistance 1 (MDR1) P-glycoprotein was the first human ATP-binding cassette $(\mathrm{ABC})$ transporter to be identified and has the ability to mediate multidrug resistance in cancer cells. Multidrug resistance-associated proteins (MRP) including MRP1 and 2 are also involved in multidrug resistance in cancer chemotherapy. These proteins act as ATP-dependent molecular pumps that extrude a number of anticancer drugs from the cells, which results in decreases in their intracellular concentrations. ${ }^{1-4)}$

MRP1 was identified in the non-P-glycoprotein multidrugresistant small cell lung cancer cell line H69 after stepwise exposure to doxorubicin. ${ }^{5,6)}$ MRP1 shows relatively ubiquitous expression, whereas MRP2, which was initially identified as a canalicular organic anion transporter, is restricted mainly to the renal, intestinal and hepatic epithelia. Since there is extensive overlapping of the tissue distributions of Pglycoprotein and MRP2, it is likely that these two proteins play cooperative roles in pharmacological and toxicological protective functions, by mediating the efflux of different (but partially overlapping) sets of substrates. ${ }^{7,8)}$ P-glycoprotein extrudes large hydrophobic molecules that are uncharged or positively charged, while the members of the MRP family tend to pump out both hydrophobic uncharged molecules and water-soluble anionic compounds. The lung resistance protein (LRP), which is the major component of complex ribonucleoprotein particles called "vaults," was detected in a non-P-glycoprotein lung cancer cell line. ${ }^{9)}$ Like P-glycoprotein and MRP, LRP expression by tumor cell lines is believed to be associated with resistance to various anticancer drugs, ${ }^{10)}$ though the molecular function of LRP remains to be fully elucidated.

Retinoblastomas are a rare intraocular malignancy occurring in early childhood. They occur in 1 in 15000 to 20000 live births irrespective of ethnicity or gender. The management of retinoblastomas is complex and includes enucleation and non-enucleation (conservative) techniques. ${ }^{11)}$ Retinoblastomas have traditionally been treated by enucleation of the affected eye and/or a combination of radiation therapy, cryotherapy or focal laser therapy. ${ }^{11)}$ Though external beam radiotherapy has been a standard treatment for retinoblastomas, it increases the risk of cosmetic deformities and secondary malignant tumors in the field of irradiation. Currently, the most popular conservative technique is primary systemic chemotherapy, which is also called chemoreduction. ${ }^{12)}$

Chan et al. ${ }^{13)}$ reported that increased expression of P-glycoprotein was detected in multidrug-resistant retinoblastoma cell lines as well as in the tumors from which the cell lines were derived, while drug-sensitive retinoblastoma cell lines were negative for P-glycoprotein staining. Subsequently, clinical studies showed that supplementation of cyclosporin A, an inhibitor of P-glycoprotein, to the chemoreduction regimen improved the treatment of retinoblastomas without radiation. ${ }^{14)}$ Later, it was shown that MRP1, but not P-glycoprotein, was expressed in all three retinoblastomas that became enucleated immediately after failure of chemotherapy with cyclosporin A. ${ }^{15)}$ Furthermore, Krishnakumar et al. ${ }^{16)}$ observed the expression of P-glycoprotein and LRP in retinoblastomas. Thus, it is likely that several drug transporters including $\mathrm{ABC}$ transporters and LRP are involved in the 
multidrug resistance in retinoblastomas.

The Y79 retinoblastoma cell line was first established from a primary human retinoblastoma tumor ${ }^{17)}$ and has been used for several decades as a prototype for retinoblastomas. Y79 cells have been used as an in vitro model to study the mechanisms underlying retinal tumor growth. In addition, in vivo models of human retinoblastomas can be generated by injecting Y79 cells into the eyes of experimental animals. ${ }^{18,19)}$ Thus, in vitro and in vivo studies involving Y79 cells have provided an opportunity to develop and improve the chemotherapy for retinoblastomas. In this study, the expression of P-glycoprotein and MRP mRNA was examined in Y79 cells. Furthermore, we analyzed the cellular accumulation of substrates of P-glycoprotein and/or MRP in the absence or presence of various inhibitors of them.

\section{MATERIALS AND METHODS}

Materials Rhodamine 123 was purchased from Kanto Chemical Co., Inc. (Tokyo, Japan). Calcein acetoxymethyl ester (calcein-AM), doxorubicin hydrochloride, verapamil hydrochloride, glibenclamide, quinidine and genistein were purchased from Wako Pure Chemical Industries, Ltd. (Osaka, Japan). Probenecid, indomethacin, nicardipine hydrochloride and nifedipine were purchased from Sigma Chemicals Co. (St. Louis, MO, U.S.A.). Cyclosporin A was kindly supplied by Novartis Pharma K.K. (Tokyo, Japan). Tacrolimus was a generous gift from Astellas Pharm. Inc. (Tokyo, Japan). All other chemicals used in the experiments were commercial products of the highest purity available.

Cell Culture Human retinoblastoma cell line Y79 was obtained from the Riken Cell Bank (Ibaraki, Japan). Y79 cells were cultured in suspension in RPMI1640 culture medium supplemented with $10 \%$ fetal bovine serum (FBS), 100 units $/ \mathrm{ml}$ penicillin and $100 \mu \mathrm{g} / \mathrm{ml}$ streptomycin. The cells were grown in $25 \mathrm{~cm}^{2}$ culture flasks in the upright position in $10 \mathrm{ml}$ aliquots of the culture medium. Incubation was performed at $37^{\circ} \mathrm{C}$ under a humidified atmosphere of $5 \%$ $\mathrm{CO}_{2}-95 \%$ air. Once per week the contents of each flask were collected by centrifugation and seeded into fresh medium at a cell density of $20 \times 10^{4}$ cells $/ \mathrm{ml}$. A549 cells, a human lung carcinoma cell line, were obtained from the Riken Cell Bank, and were cultured with Dulbecco's modified Eagle's medium (DMEM) supplemented with 10\% FBS, 100 units/ml peni- cillin and $100 \mu \mathrm{g} / \mathrm{ml}$ streptomycin. The cells were cultured at $37^{\circ} \mathrm{C}$ under a humidified atmosphere of $5 \% \mathrm{CO}_{2}-95 \%$ air. A549 cells were subcultured every $7 \mathrm{~d}$ and the medium was replaced with fresh medium every $2-3 \mathrm{~d}$. Caco- 2 cells, a human intestinal cell line, were cultured as described previously. $^{20)}$

Conventional Reverse-Transcription-Polymerase Chain Reaction (RT-PCR) Analysis Total RNA was extracted from Y79 cells using a MagExtractor RNA kit (TOYOBO). RT-PCR was performed using a ReverTra Dash RT-PCR kit (TOYOBO, Osaka, Japan) as described previously. ${ }^{21)}$ The amplification reaction steps comprised denaturation at $94{ }^{\circ} \mathrm{C}$ for $30-60 \mathrm{~s}$, followed by annealing for $30-60 \mathrm{~s}$ and extension at $72{ }^{\circ} \mathrm{C}$ for $30-60 \mathrm{~s}$. The primer sequence, annealing temperature, cycle numbers and product sizes of the MDR1, MRP1, MRP2, LRP, pregnane X receptor (PXR), and glyceraldehyde-3-phosphate dehydrogenase (GAPDH) genes are shown in Table 1 . The PCR products were separated by electrophoresis in a $2.0 \%$ agarose gel and stained with ethidium bromide.

Real-Time PCR Real-time PCR was performed using SYBR Green Realtime PCR Master Mix (TOYOBO Co., Ltd.). Total RNA was extracted using RNeasy kit (Qiagen, Valencia, CA, U.S.A.) from Y79 cells and Caco-2 cells cultured for $4 \mathrm{~d}$ and $21 \mathrm{~d}$ after seeding, respectively. Total RNA $(0.1 \mu \mathrm{g})$ was reverse transcribed with oligo(dT) primers using a ReverTra Dash RT-PCR kit (TOYOBO CO., LTD.). The primer pair of MDR1, sense and antisense (sense: $5^{\prime}$ CCCATC ATTGCAATAGCA GG-3'; antisense: 5'-TGTTCAAAC TTCTGCTCCTGA-3'), was specific for a 158 -bp fragment of MDR1 transcripts. The primer pair of MRP1, sense and antisense (sense: 5'-GTGTTTCTGGTCAGCCCAACT-3'; antisense: 5'-TTGGATCTCAGGATGGCTAGG$3^{\prime}$ ), was specific for a 155-bp fragment of MRP1 transcripts. The primer pair of MRP2 sense and antisense (sense: $5^{\prime}$ TGAGCAAGTTTGAAACGCACAT-3'; antisense: 5'-AGCTCTTCTCCTGCCGTCTCT-3') was specific for a 78-bp fragment of MRP2 transcripts. The primer pair of GAPDH, sense and antisense (sense: 5' -CCACCCATGGCAAATTCC3'; antisense: 5'-TGGGATTTCCATTGATGACAA-3'), was specific for a 69-bp fragment of GAPDH transcripts. The PCR conditions comprised initial denaturation at $95^{\circ} \mathrm{C}$ for $1 \mathrm{~min}$, followed by amplification for 48 cycles of $5 \mathrm{~s}$ at $95^{\circ} \mathrm{C}$, $5 \mathrm{~s}$ at $60^{\circ} \mathrm{C}$, and $15 \mathrm{~s}$ at $72^{\circ} \mathrm{C}$. The threshold cycle $(\mathrm{Ct})$ val-

Table 1. Conventional RT-PCR Primer Sequences, Annealing Temperatures, Cycle Numbers and Product Sizes

\begin{tabular}{|c|c|c|c|c|}
\hline & Primer sequence $\left(5^{\prime} \rightarrow 3^{\prime}\right)$ & Annealing temperature & Cycle number & PCR product size \\
\hline MDR1 & $\begin{array}{l}\text { Sense: GTCATTGTGGAGAAAGGAAATCATG } \\
\text { Antisense: ATTCCAAGGGCTAGAAACAATAGTG }\end{array}$ & $64^{\circ} \mathrm{C}$ & 34 & $479 \mathrm{bp}$ \\
\hline MRP1 & $\begin{array}{l}\text { Sense: CTGTTTTGTTTTCGGGTTCC } \\
\text { Antisense: CCAAGGCCTTCCAAATCTC }\end{array}$ & $62^{\circ} \mathrm{C}$ & 23 & 498 bp \\
\hline MRP2 & $\begin{array}{l}\text { Sense: ACACCAACCAGAAATGTGTC } \\
\text { Antisense: CCAAGGCCTTCCAAATCTC }\end{array}$ & $62^{\circ} \mathrm{C}$ & 30 & $659 \mathrm{bp}$ \\
\hline LRP & $\begin{array}{l}\text { Sense: GAGGATAAAGATGGAGACAA } \\
\text { Antisense: GAGAATCACGCAGTAGTTGTGG }\end{array}$ & $58^{\circ} \mathrm{C}$ & 24 & 467 bp \\
\hline PXR & $\begin{array}{l}\text { Sense: CAAGCGGAAGAAAAGTGAACG } \\
\text { Antisense: CTGGTCCTGGATGGGCAAGT }\end{array}$ & $68^{\circ} \mathrm{C}$ & 31 & 442 bp \\
\hline GAPDH & $\begin{array}{l}\text { Sense: GCAGGGGGGAGCCAAAAGGG } \\
\text { Antisense: TGCCAGCCCCAGCGTCAAAG }\end{array}$ & $69^{\circ} \mathrm{C}$ & 19 & $567 \mathrm{bp}$ \\
\hline
\end{tabular}


ues for each mRNA were determined using the second derivative maximum method and were used to quantitate gene expression. After amplification, melt analysis was performed by heating the reaction mixture from 65 to $95^{\circ} \mathrm{C}$. The melt curves were transformed to negative first-derivative melting ones ([-dF/dt] vs. temperature). The negative first-derivative peaks were used to identify specific PCR products because a peak is characteristic of the respective PCR product's melt temperature. The expression of target genes was normalized as to the level of GAPDH.

Intracellular Accumulation Studies Intracellular accumulation studies involving fluorescent substrates for P-glycoprotein and MRP were performed as previously reported by our and other groups with some modifications. ${ }^{20,22-25)}$ Y79 cells grown in culture flasks were collected by centrifugation, washed and resuspended in Dulbecco's phosphate-buffered saline (137 mM NaCl, $3 \mathrm{~mm} \mathrm{KCl,} 8 \mathrm{~mm} \mathrm{Na} \mathrm{HPO}_{4}, 1.5 \mathrm{~mm}$ $\mathrm{KH}_{2} \mathrm{PO}_{4}, 1 \mathrm{~mm} \mathrm{CaCl}, 0.5 \mathrm{~mm} \mathrm{MgCl}_{2}, \mathrm{pH}$ 7.4) supplemented with $5 \mathrm{mM}$ D-glucose $[\mathrm{PBS}(\mathrm{G})]$. After the cell suspension $\left(250 \times 10^{4}\right.$ cells $\left./ 200 \mu \mathrm{l}\right)$ had been mixed with $200 \mu \mathrm{l}$ of $\operatorname{PBS}(\mathrm{G})$ without or with P-glycoprotein and/or MRP inhibitor, the cells were preincubated for $15 \mathrm{~min}$ at $37^{\circ} \mathrm{C}$. Then, $400 \mu \mathrm{l}$ of the $\operatorname{PBS}(\mathrm{G})$ containing rhodamine 123 , calcein-AM or doxorubicin without or with each inhibitor was added. The concentrations of substrates and inhibitors for P-glycoprotein and/or MRP used in this study were determined based on previous data obtained by our and others groups. ${ }^{23,25-29)}$ The final concentrations of dimethyl sulfoxide and ethanol, which was used as a solvent, were less than $0.65 \%$ and $4 \%$, respectively, at which no significant effects on the accumulation of each substrate were observed in a preliminary study. After incubation at $37^{\circ} \mathrm{C}$ for the indicated periods, the cells were centrifuged at $3500 \mathrm{rpm}$ for $3 \mathrm{~min}$ at $4{ }^{\circ} \mathrm{C}$ in an Avanti 30 Compact Centrifuge with a rotor F3602. After removal of the supernatant, the cells were washed with $1 \mathrm{ml}$ of ice-cold-PBS(G) and centrifuged at $3500 \mathrm{rpm}$ for $3 \mathrm{~min}$ at $4{ }^{\circ} \mathrm{C}$. The cells were then solubilized with $600 \mu \mathrm{l}$ of $0.1 \%$ Triton $\mathrm{X}-100$ in $1 \mathrm{~mm} N$-(2-hydroxyethyl)piperazine$N^{\prime}$-2-ethanesulfonic acid (HEPES)/Tris buffer (for rhodamine 123 or calcein-AM) or $1 \%$ SDS in $1 \mathrm{mM} \mathrm{HEPES/Tris}$ buffer (for doxorubicin). Aliquots were used to determine the concentration of each substrate. The intracellular fluorescence was measured using a Hitachi fluorescence spectrophotometer F-3000 (Tokyo, Japan) at an excitation wavelength (485 $\mathrm{nm}$ for rhodamine 123, $490 \mathrm{~nm}$ for calcein, 470 $\mathrm{nm}$ for doxorubicin) and an emission wavelength (538 nm for rhodamine $123,515 \mathrm{~nm}$ for calcein, $585 \mathrm{~nm}$ for doxorubicin). Protein content was determined by the Bradford method ${ }^{30}$ ) for the rhodamine 123 and calcein transport study, and by the Lowry method ${ }^{31)}$ for the doxorubicin transport study with bovine serum albumin as a standard. The accumulation of these fluorescent probes was normalized as to the protein content of the cells in each tube.

Statistical Analysis Statistically significant differences were determined with Student's $t$-test, or one way analysis of variance (ANOVA) with Tukey-Kramer's test for post hoc analysis. A $p$ value of less than 0.05 was considered statistically significant.

\section{RESULTS}

Expression of MDR1, MRP1, MRP2, LRP and PXR mRNA in Y79 Cells Using specific primers, the expression of mRNAs for MDR1 (P-glycoprotein), MRP1, MRP2, LRP and PXR in Y79 cells was analyzed by conventional RT-PCR analysis. As shown in Fig. 1, PCR amplification with reverse transcription of total RNA from Y79 cells gave a product from each mRNA examined in this study. No band was detected when the total RNA from Y79 cells was subjected to PCR without reverse transcription. For comparison (described later in detail), the expression of mRNA for MDR1 in human lung adenocarcinoma A549 cells was examined. The band was more clearly detected in A549 cells than in Y79 ones. Furthermore, we performed real-time PCR in order to quantitatively determine the expression levels of mRNAs for MDR1, MRP1 and MRP2 in Y79 cells. As a positive control, human intestinal cell line Caco-2 expressing MDR1, MRP1 and MRP2 mRNAs was employed. The expression levels of the MDR1 and MRP2 genes in Y79 cells were 1809- and 136-fold lower than those in Caco-2 cells, respectively. In contrast, the expression level of MRP1 mRNA was 11.1-fold greater than that in Caco-2 cells.

Effects of Various Inhibitors on Accumulation of PGlycoprotein Substrate Rhodamine 123 The accumulation of rhodamine 123, a typical P-glycoprotein substrate, ${ }^{3,32)}$ was characterized in Y79 cells. When Y79 cells were incubated with various concentrations of rhodamine 123 for $2 \mathrm{~h}$ at $37^{\circ} \mathrm{C}$, the accumulation of rhodamine 123 increased with increasing concentration in the incubation buffer (Fig. 2). Next, the effect of verapamil, a P-glycoprotein inhibitor, was investigated. Verapamil did not increase but rather decreased the accumulation of rhodamine 123 (Fig. 3). However, verapamil did not completely inhibit the accumulation of rhodamine 123 , indicating that rhodamine 123 is taken up via verapamil-sensitive and insensitive transporters. In addition, no effect of reversin 205, a chemosensitizer exhibiting high affinity to P-glycoprotein $(\mathrm{Kd}=0.154 \mu \mathrm{M}),{ }^{33)}$ on the accumulation of rhodamine 123 was observed when Y79 cells were treated with reversin 205 over the concentration range of 5 to $100 \mu \mathrm{M}$ (Fig. 4). Furthermore, cyclosporin A, a potent P-gly-

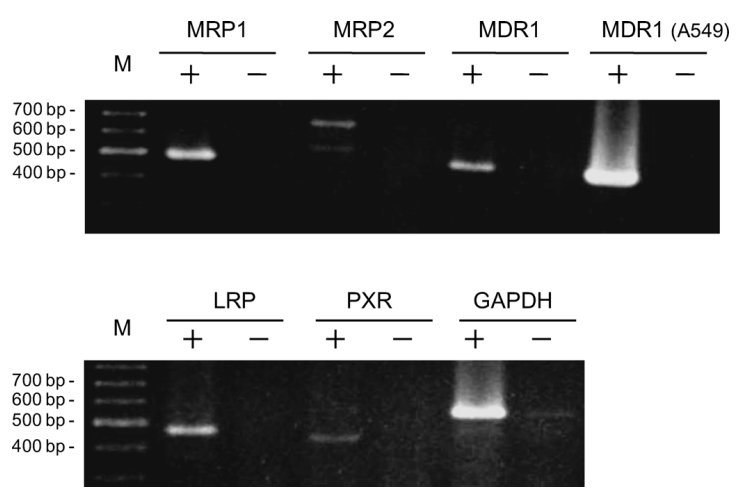

Fig. 1. RT-PCR Analysis of mRNAs of ABC Transporters (MDR1, MRP1, MRP2), LRP and PXR in Y79 Cells

Total RNA $(0.3 \mu \mathrm{g})$ from Y79 cells or A549 cells was reverse-transcribed, and firststrand cDNA synthesized was amplified with a set of specific primers described in Table 1 . The PCR products with $(+)$ or without $(-)$ reverse transcription were separated by electrophoresis through a $2 \%$ agarose gel and stained with ethidium bromide. GAPDH (glyceraldehyde-3-phosphate dehydrogenase) was used as a control. M indicates size markers. 
coprotein inhibitor, at concentrations up to $10 \mu \mathrm{M}$ had no significant effects on the rhodamine 123 accumulation. Procainamide, an inhibitor of organic cation transporters, at concentrations of up to $1 \mathrm{~mm}$ did not inhibit the accumulation of rhodamine 123 (data not shown).

Effects of Various Inhibitors on Accumulation of MRP Substrate Calcein Calcein-AM is a nonfluorescent and lipophilic acetoxymethyl ester of calcein that rapidly diffuses

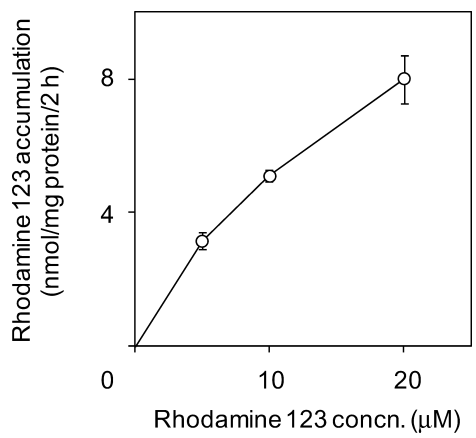

Fig. 2. Concentration-Dependent Accumulation of Rhodamine 123 in Y79 Cells

Y79 cells were incubated with 5,10 or $20 \mu \mathrm{M}$ rhodamine 123 for $2 \mathrm{~h}$ at $37^{\circ} \mathrm{C}$. Each symbol represents the mean \pm S.E. of three independent determinations. When error bars are not shown, they are included within the symbols.

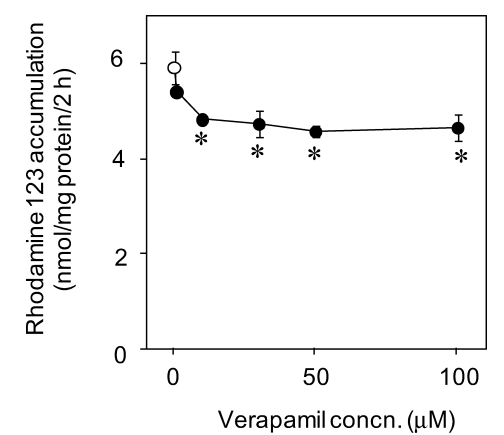

Fig. 3. Effect of Verapamil on Rhodamine 123 Accumulation in Y79 Cells

Y79 cells were preincubated without (control, open circle) or with 1, 10, 30, 50 or $100 \mu \mathrm{M}$ verapamil (closed circles) for $15 \mathrm{~min}$ at $37^{\circ} \mathrm{C}$. Then, $20 \mu \mathrm{M}$ rhodamine 123 in the absence or presence of verapamil was added and the accumulation was measured after $2 \mathrm{~h}$ incubation at $37^{\circ} \mathrm{C}$. Each symbol represents the mean \pm S.E. of three independent determinations. $* p<0.05$, significantly different from the control.

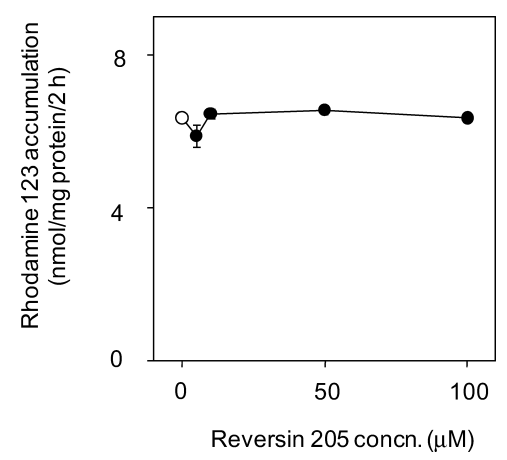

Fig. 4. Effect of Reversin 205 on Rhodamine 123 Accumulation in Y79 Cells

Y79 cells were preincubated without (control) or with 5, 10, 50 or $100 \mu \mathrm{M}$ reversin 205 for $15 \mathrm{~min}$ at $37^{\circ} \mathrm{C}$. Then, $20 \mu \mathrm{M}$ rhodamine 123 in the absence or presence of reversin 205 was added and the accumulation was measured after $2 \mathrm{~h}$ incubation at $37^{\circ} \mathrm{C}$. Each symbol represents the mean \pm S.E. of three independent determinations. When error bars are not shown, they are included within the symbols. through the plasma membrane into cells. In the cytosol, calcein-AM is metabolized by esterase to calcein, a hydrophilic and highly fluorescent compound that is effluxed by MRP1 and MRP2 but not P-glycoprotein. ${ }^{25,34)}$ Thus, MRP-mediated efflux activity can be evaluated by measuring the cellular level of calcein fluorescence.

First, Y79 cells were incubated with various concentrations of calcein-AM for $2 \mathrm{~h}$ at $37^{\circ} \mathrm{C}$, and then the accumulation of calcein was examined. Calcein accumulation did not change significantly when the calcein-AM concentration was less than $500 \mathrm{~nm}$, but accumulation was markedly increased with a higher concentration of calcein-AM (1000 nM) (Fig. $5)$. This observation seems to indicate saturation of the transporter-mediated efflux of calcein from Y79 cells. To investigate the involvement of $\mathrm{ABC}$ transporters in calcein efflux, Y79 cells were incubated with calcein-AM in the absence or presence of metabolic inhibitors (10 mm 2-deoxyglucose and $5 \mathrm{~mm}$ sodium azide). Combined incubation with 2-deoxyglucose and sodium azide slightly but significantly increased the accumulation of calcein (122.3 $\pm 2.5 \%$ of control, $n=3)$.

To analyze the MRP function in Y79 cells, the effects of various inhibitors of MRP on the accumulation of calcein were examined. An MRP inhibitor, probenecid, significantly enhanced the accumulation of calcein over time, except at

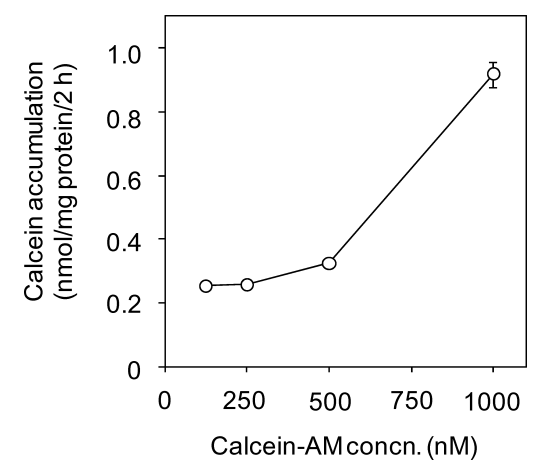

Fig. 5. Concentration-Dependent Accumulation of Calcein in Y79 Cells

Y79 cells were incubated with $125,250,500$ or $1000 \mathrm{~nm}$ calcein acetoxymethyl ester (calcein-AM) for $2 \mathrm{~h}$ at $37^{\circ} \mathrm{C}$. Each symbol represents the mean \pm S.E. of three independent determinations. When error bars are not shown, they are included within the symbols.

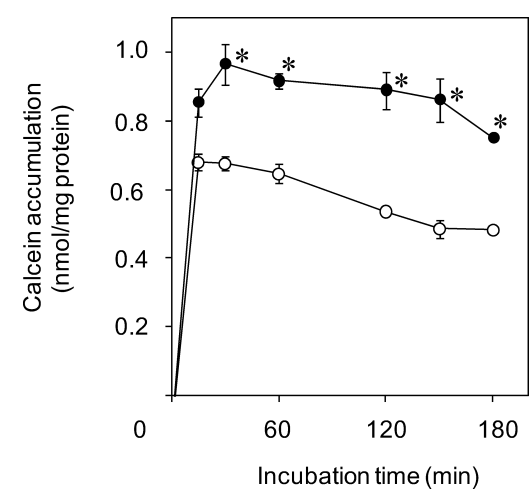

Fig. 6. Effect of Probenecid on Calcein Accumulation in Y79 Cells

Y79 cells were preincubated without (control, open circles) or with $1 \mathrm{~mm}$ probenecid (closed circles) for $15 \mathrm{~min}$ at $37^{\circ} \mathrm{C}$. Then, $1 \mu \mathrm{M}$ calcein-AM in the absence or presence of $1 \mathrm{~mm}$ probenecid was added and the accumulation was measured after incubated for $15,30,60,120,150$ and $180 \mathrm{~min}$ at $37^{\circ} \mathrm{C}$. Each symbol represents the mean \pm S.E. of three independent determinations. $* p<0.05$, significantly different from the control at the same incubation time. 
Table 2. Effects of Various MRP Inhibitors on Calcein Accumulation in Y79 Cells

\begin{tabular}{ll}
\hline \hline \multicolumn{1}{c}{ MRP inhibitors } & $\%$ of control \\
\hline Probenecid $(1 \mathrm{~mm})$ & $155 \pm 4.2^{*}$ \\
Glibenclamide $(100 \mu \mathrm{M})$ & $171 \pm 3.4^{*}$ \\
Indomethacin $(100 \mu \mathrm{M})$ & $148 \pm 3.5$ \\
Cyclosporin A $(20 \mu \mathrm{M})$ & $266 \pm 10^{*}$ \\
Bromocresol green $(1 \mathrm{mM})$ & $202 \pm 4.2^{*}$ \\
\hline
\end{tabular}

Y79 cells were preincubated without (control) or with each inhibitor for $15 \mathrm{~min}$ at $37^{\circ} \mathrm{C}$. Then, $1 \mu \mathrm{M}$ calcein-AM in the absence or presence of the inhibitor was added and the accumulation was measured after $2 \mathrm{~h}$ incubation at $37^{\circ} \mathrm{C}$. Values are expressed as percentages of the control value and are the means \pm S.E. of three independent determinations. $* p<0.05$, significantly different from the control.

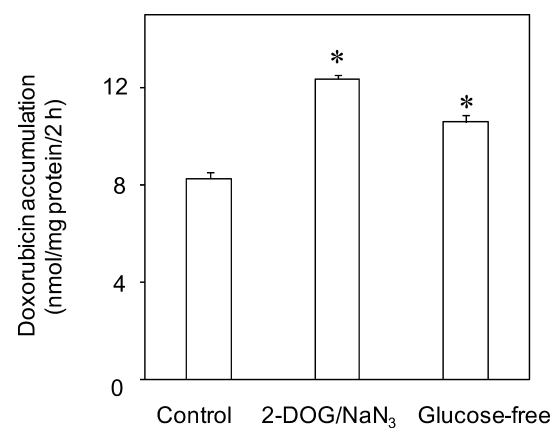

Fig. 7. Effects of Metabolic Inhibitiors and Glucose Removal on Doxorubicin Accumulation in Y79 Cells

Y79 cells were treated without (control) or with the combination of 2-deoxyglucose (2-DOG, $10 \mathrm{~mm})$ and sodium azide $\left(\mathrm{NaN}_{3}, 5 \mathrm{~mm}\right)$ or with the buffer without glucose (glucose-free). After pretreated for $15 \mathrm{~min}, 20 \mu \mathrm{M}$ doxorubicin was added and the accumulation was measured after incubated for $2 \mathrm{~h}$ at $37^{\circ} \mathrm{C}$. Each column represents the mean \pm S.E. of three independent determinations. $* p<0.05$, significantly different from the control.

Table 3. Effects of Various MRP and/or P-glycoprotein Inhibitors on Doxorubicin Accumulation in Y79 Cells

\begin{tabular}{cc}
\hline \hline Inhibitors & $\%$ of control \\
\hline MRP inhibitors & \\
Probenecid $(1 \mathrm{~mm})$ & $97.8 \pm 5.6$ \\
Glibenclamide $(100 \mu \mathrm{M})$ & $112 \pm 6.1$ \\
Genistein $(200 \mu \mathrm{M})$ & $106 \pm 4.8$ \\
Quercetin $(30 \mu \mathrm{M})$ & $93.5 \pm 10$ \\
MRP/P-glycoprotein inhibitors & \\
Cyclosporin A $(20 \mu \mathrm{M})$ & $224 \pm 3.8^{*}$ \\
Tacrolimus $(10 \mu \mathrm{M})$ & $210 \pm 1.5^{*}$ \\
P-glycoprotein inhibitors & \\
Nicardipine $(50 \mu \mathrm{M})$ & $154 \pm 3.3^{*}$ \\
Nifedipine $(10 \mu \mathrm{M})$ & $91.8 \pm 2.4$ \\
Quinidine $(100 \mu \mathrm{M})$ & $84.2 \pm 4.6$ \\
Verapamil $(100 \mu \mathrm{M})$ & $92.5 \pm 1.5$
\end{tabular}

Y79 cells were preincubated without (control) or with each inhibitor for $15 \mathrm{~min}$ at $37^{\circ} \mathrm{C}$. Then, $20 \mu \mathrm{m}$ doxorubicin in the absence or presence of the inhibitor was added and the accumulation was measured after $2 \mathrm{~h}$ incubation at $37^{\circ} \mathrm{C}$. Values are expressed as percentages of the control and are the mean \pm S.E. from three independent determinations. $* p<0.05$, significantly different from control.

$15 \mathrm{~min}$ (Fig. 6). In addition, the accumulation of calcein after $2 \mathrm{~h}$ incubation was significantly increased by various MRP inhibitors, including probenecid, glibenclamide, cyclosporin A and bromocresol green (Table 2). Thus, it was shown that MRP functions in Y79 cells, though the member of the MRP family involved in the efflux of calcein has not been identified in this study.

Effects of Various Inhibitors on Accumulation of Doxo-

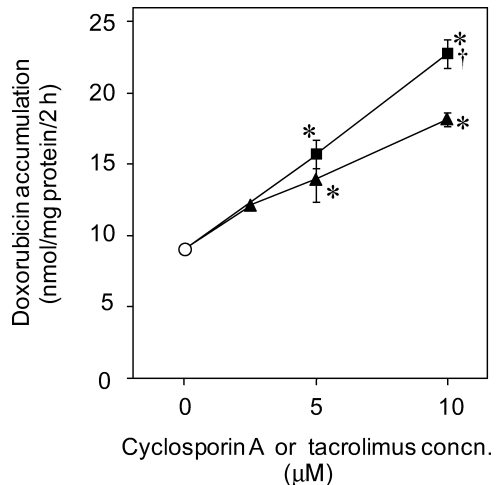

Fig. 8. Effect of Cyclosporin A or Tacrolimus on Doxorubicin Accumulation in Y79 Cells

Y79 cells were preincubated without (control, open circle) or with cyclosporin A $(2.5,5,10 \mu \mathrm{M})$ (closed triangles) or tacrolimus $(5,10 \mu \mathrm{M})$ (closed squares) for $15 \mathrm{~min}$ at $37^{\circ} \mathrm{C}$. Then, $20 \mu \mathrm{M}$ doxorubicin in the absence or presence of cyclosporin A or tacrolimus was added and the accumulation was measured after $2 \mathrm{~h}$ incubation at $37^{\circ} \mathrm{C}$. Each symbol represents the mean \pm S.E. of three independent determinations. $* p<0.05$, significantly different from the control. $\dagger p<0.05$, significantly different from the value for the cells treated with the same concentration as that of cyclosporin A.

rubicin in Y79 Cells The accumulation of anticancer drug doxorubicin, a substrate of P-glycoprotein and MRP, was examined in Y79 cells. Like that of calcein, doxorubicin accumulation was significantly increased by the combination of 2-deoxyglucose and sodium azide, and by glucose depletion from the incubation buffer (Fig. 7). Next, we examined the effects of various P-glycoprotein and/or MRP inhibitors on the accumulation of doxorubicin (Table 3). As expected from the above-mentioned results showing the lack of a P-glycoprotein function, doxorubicin accumulation was not enhanced by verapamil, quinidine or nifedipine, which inhibit P-glycoprotein. However, unexpectedly, MRP inhibitors such as probenecid, glibenclamide, genistein and quercetin also had no effect on doxorubicin accumulation. Among the inhibitors tested, cyclosporin A, tacrolimus and nicardipine significantly increased the accumulation of doxorubicin. Tacrolimus more potently enhanced the accumulation of doxorubicin than cyclosporin A (Fig. 8).

\section{DISCUSSION}

In the presents study, we investigated the expression and function of $\mathrm{ABC}$ transporters in the Y79 retinoblastoma cell line, a prototype for retinoblastoma cells. Y79 cells exhibits disruption of exons 2 through 6 of the retinoblastoma (RB) gene. $^{35)}$ In addition, Y79 cells express marker proteins that are observed in solid retinal tumors ${ }^{36,37)}$ and can be induced to differentiate along several lineages. ${ }^{38,39)}$ Therefore, Y79 cells have been used as an in vitro model to study the mechanisms underlying retinal tumor growth. Furthermore, it has been reported that in vivo models of human retinoblastomas, which are generated by injecting Y79 cells into the eyes of experimental animals, may provide a useful opportunity for facilitating the evaluation of antitumoral treatments for retinoblastomas under in vivo conditions. ${ }^{18,19)}$

RT-PCR analysis showed that MDR1 mRNA was expressed in the Y79 cells employed in this study. However, the accumulation study involving rhodamine 123 did not show that P-glycoprotein functions in Y79 cells. Previously, we observed that human lung carcinoma A549 cells, in which 
MDR1 mRNA was more abundantly detected than that in Y79 cells (Fig. 1), did not express P-glycoprotein at the protein level. ${ }^{25}$ In addition, the accumulation of rhodamine 123 in A549 cells was not enhanced by P-glycoprotein inhibitors including verapamil. Thus, these observations may be explained by a failure of translation of the mRNA followed by a lack of P-glycoprotein expression and its activity. Yoo et $a l .{ }^{40)}$ reported that $\mathrm{P}$-glycoprotein expression was increased by enhanced expression of a retinoblastoma protein $(\mathrm{Rb})$, a product of the gene that is dysfunctional in retinoblastomas and many kinds of tumors. Since normal $\mathrm{Rb}$ protein was completely absent from Y79 cells, ${ }^{35)}$ it may be involved in the absence of a P-glycoprotein function in Y79 cells.

In contrast with in the case of P-glycoprotein, not only the expression of MRP1 and MRP2 mRNA but also MRP-mediated efflux activity was observed in Y79 cells. The RT-PCR product band of MRP1 mRNA was clearly detected after 23 PCR cycles, whereas the band of MRP2 mRNA was only weakly detected after 30 PCR cycles. Though the present experimental settings do not allow us to compare quantitatively the amounts of different mRNAs, it is likely that MRP1 mRNA might be more abundant than MRP2 mRNA in Y79 cells. This might be supported by the present observation on real-time PCR that the mRNA level of MRP1, but not those of MDR1 and MRP2, in Y79 cells was comparatively higher than that in Caco-2 cells. So far, several researchers have reported the expression of P-glycoprotein and MRP in retinoblastoma patients. Chan et al. $^{15)}$ reported that the expression of P-glycoprotein and MRP1 was observed in 3 $(16.6 \%)$ and $1(5.5 \%)$ of 18 samples from primarily enucleated patients, respectively. Wilson et $a l^{41)}$ compared the expression of $\mathrm{ABC}$ transporters including P-glycoprotein and MRP in retinoblastoma tumors from eyes treated with primary enucleation. According to the paper, the expression of P-glycoprotein, MRP1 and MRP2 was positive in $2(12 \%), 8$ $(50 \%)$, and $5(31 \%)$ of the 16 tumors studied, respectively, while no expressions of MRP4 or breast cancer resistance protein (BCRP) was observed. The simultaneous expression of MRP1 and MRP2 was observed in $2(12 \%)$ of 16 samples. More recently, it was reported that P-glycoprotein and MRP1 expression was positive in $69.3 \%$ and $74.3 \%$ of 65 enucleated eyes, respectively. ${ }^{42)}$ In this study, Y79 cells were shown to express PXR mRNA. PXR, one of the ligand-regulated orphan nuclear receptors, regulates the expression of drug metabolizing enzyme genes such as those of the cytochrome P450 family as well as drug transporter genes including that of MDR1. ${ }^{43}$ Therefore, possible differences in gene regulation by PXR may, at least in part, explain the variability in the expression frequencies of $\mathrm{ABC}$ transporters among retinoblastoma patients. It is reported that Y79 cells express the mRNAs encoding retinoid X receptor members ( $\mathrm{RXR} \alpha$, $\operatorname{RXR} \beta, \operatorname{RXR} \gamma),{ }^{44)}$ which heterodimerize with PXR. ${ }^{45)}$ Thus, not only PXR ligands including rifampicin but also RXR ligands such as 9-cis retinoic acid might regulate the expression and function of ABC transporters in Y79 cells. Further studies are needed to clarify the involvement of these $A B C$ transporters in the multidrug resistance in retinoblastomas.

In the present study, in order to examine whether the functions of P-glycoprotein and MRP were present in Y79 cells, the accumulation studies were performed employing rhodamine 123 and calcein as substrates for P-glycoprotein and
MRP, respectively. When Y79 cells were incubated with various concentrations of rhodamine 123 , the accumulation of rhodamine 123 was apparently saturable, which might indicate the involvement of transporters in the uptake process, rather than in the efflux process (Fig. 2). The involvement of uptake transporter in rhodamine 123 influx might be supported by the observation that verapamil inhibited the accumulation of rhodamine 123 in a concentration-dependent manner (Fig. 3). Considering that reversin 205, a selective inhibitor for P-glycoprotein, (Fig. 4) and cyclosporin A (10 $\mu \mathrm{M}$, data not shown) had no significant effect on rhodamine 123 accumulation, there seems to be little P-glycoprotein activity in Y79 cells. In contrast with rhodamine 123 accumulation, the accumulation of calcein increased disproportionally with increasing concentration of calcein-AM (Fig. 5), which indicates a saturation of transporter-mediated efflux of calcein from Y79 cells. Furthermore, the enhanced accumulation of calcein by MRP inhibitors including probenecid (Fig. 6, Table 2) showed an involvement of MRP in the efflux of calcein from Y79 cells. Taken together, MRP, but not P-glycoprotein, functions in Y79 cells.

Recently, Hendig et al. $^{46)}$ investigated the gene expression profile of $47 \mathrm{ABC}$ transporters including MDR1 and MRP19 in Y79 cells using an ABC Transporter TaqMan Lowdensity Array. According to the report, MRP1 and MRP4 mRNAs were highly expressed, while the mRNA levels for MRP2 and MRP6 were low, and MRP3 mRNA was not expressed in Y79 cells. Furthermore, they detected MRP-like efflux activity in Y79 cells by examining the effect of an MRP inhibitor MK-571 on intracellular calcein remaining. In the present study, we clarified that calcein efflux from Y79 cells was saturable, ATP-dependent and was decreased by various MRP inhibitors, which confirms the presence of MRP function in Y79 cells. On the other hand, Hendig et $a l .{ }^{46)}$ reported no gene expression for MDR1 gene in Y79 cells though we detected a product from MDR1 mRNA by conventional RT-PCR analysis. However, our real-time PCR study showed that the level of MDR1 mRNA in Y79 cells was much lower than that of Caco-2 cells. Therefore, MDR mRNA, if any, might be only slightly expressed in Y79 cells. Concerning the activity of P-glycoprotein, Hendig et al. ${ }^{46)}$ suggested a very low MDR activity in Y79 cells by examining intracellular rhodamine 123 by flow cytometry, but they did not show whether or not P-glycoprotein inhibitors affect rhodamine 123 efflux in Y79 cells. In this study, we observed several P-glycoprotein inhibitors such as verapamil, reversin 205 and cyclosporine A had no effect on rhodamine 123 accumulation in Y79 cells. In addition, we confirmed that immunoblot analysis revealed no expression of P-glycoprotein protein in Y79 cells (data not shown). Thus, our results might strengthen the conclusion that P-glycoprotein activity is very low or absent in Y79 cells.

Doxorubicin, an anthracycline antibiotic, is a chemotherapy drug that is used for the treatment for various types of cancer, including retinoblastomas. Since metabolic inhibitors significantly increased the accumulation of doxorubicin, a substrate for some members of the MRP family including MRP1, in Y79 cells (Fig. 7), we expected that the accumulation of doxorubicin in cells would be enhanced by MRP inhibitors, as observed in the case of calcein. However, no significant increase in doxorubicin accumulation caused by 
most MRP inhibitors including probenecid, glibenclamide and genistein was observed, exceptions being cyclosporin A and tacrolimus. The inhibitory effect of tacrolimus on doxorubicin efflux from Y79 cells was more potent than that of cyclosporin A (Fig. 8). However, considering that tacrolimus exhibits a 10- to 100-fold greater in vitro immunosuppressive activity compared with cyclosporin $\mathrm{A}$, the differences in the inhibitory potencies as to doxorubicin efflux were not so distinct compared with those in their immunosuppressive efficacies. It is unlikely that the increase in doxorubicin uptake caused by these immunosuppressants is due to the inhibition of LRP since tacrolimus did not affect doxorubicin nuclear uptake in cell lines overexpressing LRP. ${ }^{47}$ In addition, the observation that doxorubicin accumulation was increased by metabolic inhibitors (Fig. 7) may rule out the involvement of LRP since the deduced LRP amino acid sequence gave no indication of transmembrane fragments or an ATP-binding site that is characteristic of ABC transporters. ${ }^{10)}$ Among P-glycoprotein inhibitors tested in this study, nicardipine, but not verapamil or quinidine, significantly increased the accumulation of doxorubicin. So far, such an inhibition pattern for an $\mathrm{ABC}$ transporter has not been reported, as far as we know. Interestingly, Lee et $a{ }^{48}{ }^{48}$ reported that the cytotoxicity of doxorubicin towards Y79 cells was enhanced by the addition of cyclosporin A $(5 \mu \mathrm{g} / \mathrm{ml})$, but not by that of verapamil ( $3 \mu \mathrm{g} / \mathrm{ml})$. Thus, the cytotoxic effect of doxorubicin in the presence of chemosensitizer seems to be related with its effect on the accumulation of doxorubicin in Y79 cells observed in this study. It is reported that doxorubicin is a substrate of BCRP, another member of the ABC transporter family. However, we observed no expression of BCRP mRNA by RT-PCR analysis in this study, which is also consistent with the result obtained by Hendig et al. ${ }^{46}$ Therefore, it is unlikely that the efflux of doxorubicin from Y79 cells is due to BCRP.

In this study, we selected Y79 cells as an in vitro model of retinoblastomas because this cell line was established first and has been well characterized. On the other hand, it has been reported that there are some differences in sensitivity to anticancer drugs and the response to cytokine exposure between Y79 cells and other cultured retinoblastoma cells such as Rb355 and WERI-Rb ones. ${ }^{49,50)}$ In addition, retinoblastoma tumors are divided histologically into at least two cell types; partially differentiated cells and less differentiated cells. Therefore, it is necessary to compare the observations concerning the function and expression of ABC transporters in Y79 cells with those in other cultured retinoblastoma cells such as WERI-Rb-1 and RB355 ones.

In conclusion, the present study showed that Y79 cells express the mRNAs of MDR1, MRP1, MRP2, LRP and PXR. Furthermore, MRP, but not P-glycoprotein, was shown to function in Y79 cells, which is consistent with the recently published data obtained by flow cytometry. ${ }^{46)}$ In addition, it was suggested that the efflux of doxorubicin from Y79 cells may be due to an ATP-dependent transporter that has not been identified yet. These findings may be useful when in vitro and in vivo studies involving Y79 cells are performed and analyzed.

Acknowledgment This work was supported in part by a Grant-in-Aid for Scientific Research from the Ministry of Education, Culture, Sports, Science and Technology of
Japan.

\section{REFERENCES}

1) Sharom F. J., Pharmacogenomics, 9, 105-127 (2008).

2) Kruh G. D., Belinsky M. G., Oncogene, 22, 7537-7552 (2003).

3) Takano M., Yumoto R., Murakami T., Pharmacol. Ther., 109, 137 161 (2006).

4) Tian Q., Zhang J., Chan E., Duan W., Zhou S., Drug Dev. Res., 64, 118 (2005).

5) Mirski S. E., Gerlach J. H., Cole S. P., Cancer Res., 47, 2594-2598 (1987).

6) Cole S. P., Bhardwaj G., Gerlach J. H., Mackie J. E., Grant C. E., Almquist K. C., Stewart A. J., Kurz E. U., Duncan A. M., Deeley R. G., Science, 258, 1650-1654 (1992).

7) Schinkel A. H., Jonker J. W., Adv. Drug Deliv. Rev., 55, 3-29 (2003).

8) Chan L. M. S., Lowes S., Hirst B. H., Eur. J. Pharm. Sci., 21, 25-51 (2004).

9) Scheper R. J., Broxterman H. J., Scheffer G. L., Kaaijk P., Dalton W. S., van Heijningen T. H., van Kalken C. K., Slovak M. L., de Vries E. G., van der Valk P., Meijer C. J. L. M., Pinedo H. M., Cancer Res., 53 1475-1479 (1993)

10) Scheffer G. L., Wijngaard P. L., Flens M. J., Izquierdo M. A., Slovak M. L., Pinedo H. M., Meijer C. J., Clevers H. C., Scheper R., J. Nat. Med., 1, 578-582 (1995).

11) Suzuki S., Kaneko A., Int. J. Clin. Oncol., 9, 1-6 (2004)

12) Yanagisawa T., Int. J. Clin. Oncol., 9, 13-24 (2004).

13) Chan H. S., Thorner P. S., Haddad G., Gallie B. L., Ophthalmology, 98, 1425-1431 (1991).

14) Chan H. S., DeBoer G., Thiessen J. J., Budning A., Kingston J. E., O'Brien J. M., Koren G., Giesbrecht E., Haddad G., Verjee Z., Hungerford J. L., Ling V., Gallie B. L., Clin. Cancer Res., 2, 14991508 (1996).

15) Chan H. S., Lu Y., Grogan T. M., Haddad G., Hipfner D. R., Cole S. P., Deeley R. G., Ling V., Gallie B. L., Cancer Res., 57, 2325-2330 (1997).

16) Krishnakumar S., Mallikarjuna K., Desai N., Muthialu A., Venkatesan N., Sundaram A., Khetan V., Shanmugam M. P., Br. J. Ophthalmol., 88, 1521-1526 (2004).

17) Reid T. W., Albert D. M., Rabson A. S., Russell P., Craft J., Chu E. W., Tralka T. S., Wilcox J. L., J. Natl. Cancer Inst., 53, 347-360 (1974).

18) del Cerro M., Seigel G. M., Lazar E., Grover D., del Cerro C., Brooks D. H., DiLoreto D. Jr., Chader G., Invest. Ophthalmol. Vis. Sci., 34, 3336-3346 (1993)

19) Chévez-Barrios P., Hurwitz M. Y., Louie K., Marcus K. T., Holcombe V. N., Schafer P., Aguilar-Cordova C. E., Hurwitz R. L., Am. J. Pathol., 157, 1405-1412 (2000).

20) Takano M., Hasegawa R., Fukuda T., Yumoto R., Nagai J., Murakam T., Eur. J. Pharmacol., 358, 289-294 (1998).

21) Sasaki Y., Nagai J., Kitahara Y., Takai N., Murakami T., Takano M., Biochem. Biophys. Res. Commun., 282, 212-218 (2001).

22) Perloff M. D., Störmer E., von Moltke L. L., Greenblatt D. J., Pharm Res., 20, 1177-1183 (2003).

23) Patanasethanont D., Nagai J., Yumoto R., Murakami T., Sutthanut K., Sripanidkulchai B. O., Yenjai C., Takano M., J. Pharm. Sci., 96, 223233 (2007)

24) Lin Z. P., Johnson D. R., Finch R. A., Belinsky M. G., Kruh G. D., Sartorelli A. C., Mol. Cancer Ther., 1, 1105-1114 (2002).

25) Patanasethanont D., Nagai J., Matsuura C., Fukui K., Sutthanut K., Sripanidkulchai B. O., Yumoto R., Takano M., Eur. J. Pharmacol., 566, 67-74 (2007).

26) Bogush T. A., Ravcheeva A. B., Konukhova A. V., Bogush E. A., Baryshnikov A. Y., Davydov M. I., Dokl. Biochem. Biophys., 405, $441-444$ (2005).

27) van Zanden J. J., Geraets L., Wortelboer H. M., van Bladeren P. J., Rietjens I. M., Cnubben N. H., Biochem. Pharmacol., 67, 1607-1617 (2004).

28) Wang E. J., Casciano C. N., Clement R. P., Johnson W. W., Drug Metab. Dispos., 28, 522-528 (2000).

29) Shiraki N., Hamada A., Ohmura T., Tokunaga J., Oyama N., Nakano M., Biol. Pharm. Bull., 24, 555-557 (2001).

30) Bradford M. M., Anal. Biochem., 72, 248-254.

31) Lowry O. H., Rosenbrough N. J., Farr A. L., Randall R. J., J. Biol. 
Chem., 193, 265-275 (1951).

32) Kajikawa T., Mishima H. K., Murakami T., Takano M., Curr. Eye Res., 18, 240-246 (1999).

33) Sharom F. J., Yu X., Lu P., Liu R., Chu J. W., Szabó K., Müller M., Hose C. D., Monks A., Váradi A., Seprôdi J., Sarkadi B., Biochem. Pharmacol., 58, 571-586 (1999).

34) Essodaigui M., Broxterman H. J., Garnier-Suillerot A., Biochemistry, 37, 2243-2250 (1998).

35) Lee E. Y., Bookstein R., Young L. J., Lin C. J., Rosenfeld M. G., Lee W. H., Proc. Natl. Acad. Sci. U.S.A., 85, 6017-6021 (1988).

36) Kivelä T., Invest. Ophthalmol. Vis. Sci., 39, 1044-1048 (1998).

37) Wagner N., Wagner K. D., Sefton M., Rodríguez-Tébar A., Grantyn R., Invest. Ophthalmol. Vis. Sci., 41, 1932-1939 (2000).

38) Tombran-Tink J., Johnson L. V., Invest. Ophthalmol. Vis. Sci., 30, 1700-1707 (1989).

39) Albini A., Noonan D. M., Melchiori A., Fassina G. F., Percario M., Gentleman S., Toffenetti J., Chader G. J., Proc. Natl. Acad. Sci. U.S.A., 89, 2257-2261 (1992).

40) Yoo Y. D., Kang S., Kang Y. K., Biochem. Biophys. Res. Commun., 249, 6-10 (1998).
41) Wilson M. W., Fraga C. H., Fuller C. E., Rodriguez-Galindo C., Mancini J., Hagedorn N., Leggas M. L., Stewart C. F., Invest. Ophthalmol. Vis. Sci., 47, 1269-1273 (2006).

42) Kamburoğlu G., Kiratli H., Söylemezoğlu F., Bilgiç S., Ophthalmic Res., 39, 191-197 (2007).

43) Tirona R. G., Kim R. B., J. Pharm. Sci., 94, 1169-1186 (2005).

44) Li A., Zhu X., Craft C. M., Invest. Ophthalmol. Vis. Sci., 43, 13751383 (2002).

45) Xu C., Li C. Y., Kong A. N., Arch. Pharm. Res., 28, 249-268 (2005)

46) Hendig D., Langmann T., Zarbock R., Schmitz G., Kleesiek K., Götting C., Mol. Cell. Biochem., 328, 85-92 (2009).

47) Pawarode A., Shukla S., Minderman H., Fricke S. M., Pinder E. M., O’Loughlin K. L., Ambudkar S. V., Baer M. R., Cancer Chemother. Pharmacol., 60, 179-188 (2007).

48) Lee T. W., Yang S. W., Kim C. M., Hong W. S., Youn D. H., J. Korean Med. Sci., 8, 104-109 (1993).

49) Antczak C., Kloepping C., Radu C., Genski T., Müller-Kuhrt L., Siems K., de Stanchina E., Abramson D. H., Djaballah H., Invest. Ophthalmol. Vis. Sci., 50, 3065-3073 (2009).

50) Cullinan A. E., Brandt C. R., Mol. Vis., 10, 315-22 (2004). 